\title{
Mirroring the Effect of Stuffed Classes on the Utility of ESP Classes: Challenges and Students vs. Teachers Attitudes
}

\author{
Giti Karimkhanlouei \\ Zanjan University of Medical Sciences, Iran \\ Behzad Rahbar \\ Islamic Azad University, Zanjan Branch, Zanjan, Iran \\ Behzad Bayat \\ Takestan Azad University, Iran
}

\begin{abstract}
Aligned with the growing demands for higher education in Iran and rush of people to enjoy advanced education benefits, the students and teachers are facing with the problem of overcrowded classes. Thus, this paper is an attempt to investigate the perceptions and attitudes of the students and teachers towards stuffed classes. The study sample consisted of 110 students and 15 teachers both males and females. The study concentrated only on ESP classes of medical students in Zanjan University of medical sciences. Teaching large classes' questionnaire (TLCQ) was used for data collection. Questionnaire was used as research instrument. The tool was adapted from the research study of Ijaiya (1999). Data were analyzed using SPSS software for descriptive statistics. From the perspective of the teachers, they did not have a good and satisfactory attitude towards such classes and claimed that management of such classes was difficult and demanding compared to small size classes. Continuous noise from here and there in the classroom situation was a nuisance and meddled in the teaching processes while dismangled the listening students and teachers themselves. The results indicated that the teachers in such classes have to take traditionally based teaching modes of instruction mostly monotonous lectures without engaging students. The pupil could not concentrate due to various parasites such as noise. It is recommended that government and policy makers provide the education venues with appropriate facilities restrict the number of students in classes and train ample number of professional teachers to attend classes in small size. The study suggested no significant difference between males and females and also there was not a difference in the young vs. old teachers.
\end{abstract}

Index Terms - ESP, stuffed, overcrowded, medicine

\section{INTRODUCTION}

Among different causes of overcrowded classes in the world, we can refer to rapid population growth and reduction/elimination of school fees. The reality, however, is that each of these factors have influenced class size, and thus affect the quality of education (Benbow et al., 2007).

Similar to many countries and with the approaching of new millennium every year we have increasing number of medical students registering to medical universities. This problem of over crowdedness is much more paramount in the classes of Special English, since the milestone of language learning lies in the ability to communicate which cannot be attained in our present classes. In other words, English language learning and teaching in academic medical courses in parallel with other levels require ongoing involvement and participation of the students and provision of constant feedback from the teacher to gauge their progress.

The unsatisfactory result of formal and final examinations is one potent indicator arising from overpopulated classes. Interaction in such classes and communication as a basis for communicative language learning is almost impossible and murky.

In view of this, the present study was carried out to measure the attitudes of both ESP(English for specific purposes) learners and teachers towards the overpopulated classes and to compare their viewpoints.

The proportion of students to teachers according to a report by UNESCO should not exceed 1: 30 or at most a maximum of 35(teacher: student ratio; 1:35) (UNESCO, 2000, FGN,

2006).This number clarifies the opaque situation that we have in our ESP classes where in some situations we have only one teacher to feed a population of over 70 students all in the same class at the same class time. This situation overtly makes the teaching job much more demanding than is expected and also unbearable. As FME reports in 2005, overpopulated classrooms are considered to beunconducive for both teachers and students when it comes to the issue of 
continuous assessment marking and the ability to give individualized attention to students needing extra help. (FME, 2005: 5).

According to Nolasco and Arthur (1988), five likely problems of large classes are listed as follows: coping with the noise, persuading the class to use English, managing the introduction and setting up of activities, making limited resources go a long way and monitoring the work of individuals within the class (Nolasco and Arthur, 1988: 5).

Kolo and Ojo (2005) noted that teachers perceived that class work take a lot of time in teaching large classes. Other views of teacher are that exercises are not finished during the allocated time for teaching and this phenomenon makes class work to be cumbersome to be handled by one teacher; there is stress and boredom and fatigue in marking and class control. Due to these problems, many good teachers have either resigned or are frustrated. (Kolo and Ojo, 2005: -)

To deal with mentioned issues, this study concentrated on the perceptions of teachers and students on stuffed classes and the possible alternatives to tackle the problem and to face it will be put forward. Also the attitudes in terms of sex of the participants of the study and also attitudes on the basis of experience of the teachers will be analyzed. The study concentrated only on ESP classes of medical students in Zanjan university of medical sciences.

\section{The study questions:}

At the heart of this research lies the issue of increasing number of students in ESP classes and attitudes negotiating the changing context of teaching and learning ESP lessons. With this framework we shall, so to speak, be putting our theoretical following questions with which we will attempt to provide reasons for prevailing image of large ESP classes. The questions are as follows:

1. What is the general attitude of the students of medicine and pharmacy towards overcrowded classes?

2. What is the general attitude of the teachers of ESP towards overcrowded classes?

3. Is there any difference between male and female teachers of medicine in their attitudes towards overcrowded classes?

4. Is there any correlation between the students and teachers perspectives towards ESP overcrowded classes?

5. Is there any difference in male and female students' attitudes towards ESP overcrowded classes?

6. Is there any difference in teachers attitudes towards ESP overcrowded classes based on their years of experience?

\section{Methodology}

\section{Design}

The design of this study is descriptive survey research design study. Teachers' and students' perceptions were surveyed and the data was analyzed using SPSS statistical software.

\section{Subjects}

The subjects of this study comprised 110 students available from two faculties of medicine and pharmacy from Zanjan University of medical sciences. Their age range was 19-21.They were both males and females. Meanwhile, 15 teachers' perspectives on overcrowded classes were evaluated. They were both males and females and their age ranged from 28- 54. The range of their experience was 2 to 24 years. The subjects were selected on the basis of the subjects available. The teachers with more than ten years and more of experience were considered as experienced and those with less than ten years of experience were considered as young and less experienced teachers.

\section{The Instrument}

A questionnaire of TLCQ (Teaching Larges Classes Questionnaire) was distributed. It was the same questionnaire used by Ijaiya (1999). However, the validity and reliability of the items were evaluated by a pilot administration. The reliability was $72 \%$.It included 13 items in which the respondents were asked to reflect their ideas on overcrowded ESP classes. The questionnaire was administered to both students and teachers.

Accordingly, in order to prevent the level of English language proficiency from affecting the results of the answers provided by the participants both questionnaires were prepared in Persian. As Oxford and Burry -Stock (1995) mention, the advantage of using such questionnaires is that they are less time consuming than some other data elicitation techniques such as interview. However, the disadvantage attributed to questionnaires is that they cannot explain the details about the learners' responses.

The questionnaire embraced 13 items. The items were placed on a five point Likert scale of - absolutely agree (AA), agree (a), no idea $(\mathrm{N})$, disagree (DA) and totally disagree (TDA). The results were further constricted into three categories to aid in analysis.

Data Analysis

The collected data was put under evaluation using percentages, mean, standard deviation and were analyzed by applying descriptive statistics and Chi Square.

\section{RESULTS}

The research encompassed a related corollary of questions which will be considered one by one as follows:

\section{A. The First and Second Research Questions}

1. What is the general attitude of the students of medicine towards overcrowded classes? 
2. What is the general attitude of the teachers of ESP towards overcrowded classes?

The results of the two first and second research questions dealing with the attitudes of teachers and learners were amalgamated and put forward in the following table (table 1). Essentially it sought to find out if there was any relationship between the ranking of the teachers and students with regard to the problems of over-crowded classrooms. Table 1 illustrates the percentage of the items and total agreement or disagreement.

TABLE 1:

COMPARISON OF THE RESULTS OF THE ATTITUDE QUESTIONNAIRE TEACHERS AND STUDENTS GROUPS

\begin{tabular}{|c|c|c|c|c|c|c|c|c|c|}
\hline \multirow{2}{*}{$\begin{array}{l}\text { Item N } \\
o\end{array}$} & \multirow[t]{2}{*}{ Item Stem } & \multicolumn{4}{|c|}{ students' resp0nses and percentages } & \multicolumn{4}{|c|}{ teachers' responses and percentages } \\
\hline & & $\begin{array}{l}\mathrm{DA} \\
\%\end{array}$ & $\begin{array}{l}\text { NA } \\
\%\end{array}$ & $\begin{array}{l}\mathrm{A} \\
\%\end{array}$ & $\begin{array}{l}\text { Total } \\
\%\end{array}$ & $\begin{array}{l}\mathrm{DA} \\
\%\end{array}$ & $\begin{array}{l}\mathrm{NA} \\
\%\end{array}$ & $\begin{array}{l}\mathrm{A} \\
\%\end{array}$ & $\begin{array}{l}\text { Total } \\
\%\end{array}$ \\
\hline 1 & $\begin{array}{l}\text { Noise making is very rampant } \\
\text { during lessens. }\end{array}$ & $\begin{array}{l}12 \\
12.6\end{array}$ & $\begin{array}{l}11 \\
11.6\end{array}$ & $\begin{array}{l}72 \\
75.8\end{array}$ & $\begin{array}{l}95 \\
100\end{array}$ & $\begin{array}{l}0 \\
0\end{array}$ & $\begin{array}{l}0 \\
0\end{array}$ & $\begin{array}{l}15 \\
100\end{array}$ & $\begin{array}{l}15 \\
100\end{array}$ \\
\hline 2 & $\begin{array}{l}\text { Securing students' total attention } \\
\text { during lessons is almost impossible. }\end{array}$ & $\begin{array}{l}15 \\
15.8\end{array}$ & $\begin{array}{l}11 \\
11.6\end{array}$ & $\begin{array}{l}69 \\
72.5\end{array}$ & $\begin{array}{l}95 \\
100\end{array}$ & $\begin{array}{l}0 \\
0\end{array}$ & $\begin{array}{l}1 \\
6.7\end{array}$ & $\begin{array}{l}14 \\
93.3\end{array}$ & $\begin{array}{l}15 \\
100\end{array}$ \\
\hline 3 & $\begin{array}{l}\text { Many pupils at the back do not } \\
\text { participate in the lesson. }\end{array}$ & $\begin{array}{l}33 \\
34.7\end{array}$ & $\begin{array}{l}16 \\
16.8\end{array}$ & $\begin{array}{l}46 \\
48.8\end{array}$ & $\begin{array}{l}95 \\
100\end{array}$ & $\begin{array}{l}1 \\
6.7\end{array}$ & $\begin{array}{l}0 \\
0\end{array}$ & $\begin{array}{l}14 \\
93.3\end{array}$ & $\begin{array}{l}15 \\
100\end{array}$ \\
\hline 4 & Quiet students often get neglected. & $\begin{array}{l}25 \\
26.3\end{array}$ & $\begin{array}{l}28 \\
29.5\end{array}$ & $\begin{array}{l}42 \\
44.2\end{array}$ & $\begin{array}{l}95 \\
100\end{array}$ & $\begin{array}{l}1 \\
6.7\end{array}$ & $\begin{array}{l}4 \\
26.7\end{array}$ & $\begin{array}{l}10 \\
66.7\end{array}$ & $\begin{array}{l}15 \\
100\end{array}$ \\
\hline 5 & $\begin{array}{l}\text { Only brilliant students answer } \\
\text { questions in class. }\end{array}$ & $\begin{array}{l}54 \\
56.8\end{array}$ & $\begin{array}{l}21 \\
22.1\end{array}$ & $\begin{array}{l}20 \\
21.1\end{array}$ & $\begin{array}{l}95 \\
100\end{array}$ & $\begin{array}{ll}2 \\
13.3\end{array}$ & $\begin{array}{l}3 \\
20\end{array}$ & $\begin{array}{l}10 \\
66.7\end{array}$ & $\begin{array}{l}15 \\
100\end{array}$ \\
\hline 6 & $\begin{array}{l}\text { Teacher's questions cannot spread } \\
\text { round the class. }\end{array}$ & $\begin{array}{l}17 \\
17.9 \\
\end{array}$ & $\begin{array}{l}17 \\
17.9\end{array}$ & $\begin{array}{l}61 \\
64.2\end{array}$ & $\begin{array}{l}95 \\
100\end{array}$ & $\begin{array}{l}1 \\
6.7\end{array}$ & $\begin{array}{l}2 \\
13.3\end{array}$ & $\begin{array}{l}12 \\
80\end{array}$ & $\begin{array}{l}15 \\
100\end{array}$ \\
\hline 9 & $\begin{array}{l}\text { It is impossible to catch students' } \\
\text { cheating. }\end{array}$ & $\begin{array}{l}48 \\
50.5\end{array}$ & $\begin{array}{l}14 \\
14.7 \\
\end{array}$ & $\begin{array}{l}33 \\
34.7 \\
\end{array}$ & $\begin{array}{l}95 \\
100 \\
\end{array}$ & $\begin{array}{l}4 \\
26.7 \\
\end{array}$ & $\begin{array}{l}0 \\
0\end{array}$ & $\begin{array}{l}11 \\
73.3 \\
\end{array}$ & $\begin{array}{l}15 \\
100 \\
\end{array}$ \\
\hline 10 & Late- comers sneak in unnoticed. & $\begin{array}{l}23 \\
24.2\end{array}$ & $\begin{array}{l}31 \\
32.6 \\
\end{array}$ & $\begin{array}{l}41 \\
43.2 \\
\end{array}$ & $\begin{array}{l}95 \\
100\end{array}$ & $\begin{array}{l}3 \\
20\end{array}$ & $\begin{array}{l}4 \\
26.7 \\
\end{array}$ & $\begin{array}{l}8 \\
53.3 \\
\end{array}$ & $\begin{array}{l}15 \\
100\end{array}$ \\
\hline 11 & $\begin{array}{l}\text { It is difficult for students to see } \\
\text { students who are not paying } \\
\text { attention. }\end{array}$ & $\begin{array}{l}26 \\
27.4\end{array}$ & $\begin{array}{l}23 \\
24.3\end{array}$ & $\begin{array}{l}46 \\
48.4\end{array}$ & $\begin{array}{l}95 \\
100\end{array}$ & $\begin{array}{l}1 \\
6.7\end{array}$ & $\begin{array}{l}0 \\
0\end{array}$ & $\begin{array}{l}14 \\
93.3\end{array}$ & $\begin{array}{l}15 \\
100\end{array}$ \\
\hline 12 & Truants go unnoticed in the class. & $\begin{array}{l}53 \\
55.8 \\
\end{array}$ & $\begin{array}{l}10 \\
10.5\end{array}$ & $\begin{array}{l}32 \\
32.7\end{array}$ & $\begin{array}{l}95 \\
100\end{array}$ & $\begin{array}{l}4 \\
26.7\end{array}$ & $\begin{array}{l}4 \\
26.7\end{array}$ & $\begin{array}{l}7 \\
46.7\end{array}$ & $\begin{array}{l}15 \\
100\end{array}$ \\
\hline 13 & $\begin{array}{l}\text { Teaching aids cannot go round } \\
\text { everybody. }\end{array}$ & $\begin{array}{l}15 \\
15.8\end{array}$ & $\begin{array}{l}18 \\
18.9\end{array}$ & $\begin{array}{l}62 \\
65.3 \\
\end{array}$ & $\begin{array}{l}95 \\
100\end{array}$ & $\begin{array}{l}15 \\
100\end{array}$ & $\begin{array}{l}0 \\
0\end{array}$ & $\begin{array}{l}0 \\
0\end{array}$ & $\begin{array}{l}15 \\
100\end{array}$ \\
\hline
\end{tabular}

As Table (1) shows there was not a significant difference in the preliminary stage of the study between attitudes of the two groups towards ESP overcrowded classes $(\mathrm{P}<0.05)$. If we consider the 13 items closely, the whole table is a clear mirror of attitudes of the two groups of subjects toward the ESP course. With a brief look at the items and the scores, one can easily find out the attitudes of the two separate groups. As said it can be seen in the first elicitation, there was not a wide gap in the attitudes.

The table further crystallizes that the majority of the teachers had negative attitudes towards ESP overcrowded classes. In response to the item that noise making is very rampant during lessons $\% 75.8$ of the students and $\% 100$ of the teachers agreed with this item. Ijaiya,(1999) in his study on noise making classes found out that teachers teaching large classes experienced noise- making which was a barrier to effective teaching (Ijaiya, 1999: --).

In addition concerning the statement that securing students' total attention during lessons is almost impossible $72.5 \%$ (69) students agreed in parallel to $93.3 \%$ (14) of the teachers who had generally total agreement on this item. Only $48.8 \%$ (46) of the students agreed with item that "Many pupils at the back do not participate in the lesson" while 93.35 of the teachers agreed with this item.66.75\% (10) of the teachers believed that quiet students often get neglected whereas $44.2 \%$ of the students were in agreement with this item. 56.8\% (54) students disagreed with the item that "Only brilliant students answer questions in class in contrast to the teachers who $(66.7 \%)$ agreed with this statement. In the same vein, $65.3 \%$ of the students agreed that "Teachers cannot move round the class to mark students' assignments" while $86.7 \%$ of the teachers had this attitude. $73.3 \%$ of teachers perceived that it is impossible to catch students' cheating in such classes while only $33.4 \%$ of the students accepted this statement.

\section{B. The Third Research Question}

Is there any difference between male and female teachers in their attitudes towards overcrowded classes?

The third research question sought to find out whether there was any difference between attitudes of male and female students and teachers. The data did not show any significant difference between the female and male participants. The following tables are clear illustration of this finding. In this analysis the item which marked less than 50\% implied positive attitude and items scored and marked by more than $50 \%$ of the respondents were considered as entailing negative attitude. 
TABLE 2:

ATTITUDES TOWARD LARGE CLASSES IN TEACHERS' GROUP IN TERMS OF GENDER

\begin{tabular}{|c|c|c|c|c|c|}
\hline & \multirow[b]{2}{*}{ Gender } & & \multicolumn{2}{|c|}{ Teachers attitudes } & \multirow[b]{2}{*}{ Total } \\
\hline & & & $\begin{array}{l}\text { Positive } \\
\text { attitude }\end{array}$ & $\begin{array}{l}\text { Negative } \\
\text { attitude }\end{array}$ & \\
\hline \multirow[t]{4}{*}{ gender1 } & Male & Count & 1 & 8 & 9 \\
\hline & & $\%$ within gender 1 & $11.1 \%$ & $88.9 \%$ & $100.0 \%$ \\
\hline & Female & Count & 1 & 5 & 6 \\
\hline & & $\%$ within gender 1 & $16.7 \%$ & $83.3 \%$ & $100.0 \%$ \\
\hline \multirow[t]{2}{*}{ Total } & & Count & 2 & 13 & 15 \\
\hline & & $\%$ within gender 1 & $13.3 \%$ & $86.7 \%$ & $100.0 \%$ \\
\hline
\end{tabular}

TABLE 3:

CHI SQUARE TEST FOR ATTITUDES TOWARD LARGE CLASSES IN TEACHERS 'GROUP IN TERMS OF GENDER

Chi-Square Tests

\begin{tabular}{|c|c|c|c|c|c|}
\hline & Value & Df & Asymp. Sig. (2-sided) & Exact Sig. (2-sided) & Exact Sig. (1-sided) \\
\hline Pearson Chi-Square & $.096^{\mathrm{a}}$ & 1 & .756 & & \\
\hline Continuity Correction ${ }^{\mathrm{b}}$ & .000 & 1 & 1.000 & & \\
\hline Likelihood Ratio & .095 & 1 & .759 & & \\
\hline Fisher's Exact Test & & & & 1.000 & .657 \\
\hline Linear-by-Linear Association & .090 & 1 & .765 & & \\
\hline $\mathrm{N}$ of Valid Cases ${ }^{\mathrm{b}}$ & 15 & & & & \\
\hline
\end{tabular}

a. 2 cells $(50.0 \%)$ have expected count less than 5 . The minimum expected count is .80 .

b. Computed only for a $2 \times 2$ table

TABLE 4:

FREQUENCY TABLE OF ATTITUDES TOWARD LARGE CLASSES IN TEACHERS' GROUP IN TERMS OF GENDER

\begin{tabular}{|ll|l|l|l|l|}
\hline Gender & & Frequency & Percent & Valid Percent & Cumulative Percent \\
\hline Valid & male & 9 & 60.0 & 60.0 & 60.0 \\
& famale & 6 & 40.0 & 40.0 & 100.0 \\
& Total & 15 & 100.0 & 100.0 & \\
\hline
\end{tabular}

TABLE 5:

FREQUENCY TABLE OF ATTITUDES TOWARD LARGE CLASSES IN TEACHERS' GROUP IN TERMS OF POSITIVE / NEGATIVE PERCEPTIONS

\begin{tabular}{|ll|l|l|l|l|}
\hline & Attitudes & Frequency & Percent & Valid Percent & Cumulative Percent \\
\hline Valid & Positive & 2 & 13.3 & 13.3 & 13.3 \\
& negative & 13 & 86.7 & 86.7 & 100.0 \\
& Total & 15 & 100.0 & 100.0 & \\
\hline
\end{tabular}

As the above tables signify, the findings revealed that there was no significant difference in male and female teachers' perception on teaching large classes. The above findings run contrary to Ijaiya(1999) whose findings revealed that male teachers find it easier in handling large and overcrowded classes than their female counterpart both in teaching and classroom management.

\section{Research Question 4}

Is there any correlation between the attitudes of students and teachers' perspectives towards ESP overcrowded classes?

The result of the analysis showed that there was an agreement between the views of students and teachers on the issue. 
TABLE 6:

TEACHERS AND STUDENTS ATTITUDES

\begin{tabular}{|c|c|c|c|c|c|}
\hline & \multirow{2}{*}{\multicolumn{2}{|c|}{$\begin{array}{l}\text { Teachers vs. } \\
\text { students } \\
\text { attitudes }\end{array}$}} & \multicolumn{2}{|l|}{ Attitude } & \multirow[b]{2}{*}{ Total } \\
\hline & & & Positive & Negative & \\
\hline \multirow[t]{4}{*}{ Group } & student & Count & 33 & 62 & 95 \\
\hline & & $\%$ within group & $34.7 \%$ & $65.3 \%$ & $100.0 \%$ \\
\hline & teacher & Count & 2 & 13 & 15 \\
\hline & & $\%$ within group & $13.3 \%$ & $86.7 \%$ & $100.0 \%$ \\
\hline \multirow[t]{2}{*}{ Total } & & Count & 35 & 75 & 110 \\
\hline & & $\%$ within group & $31.8 \%$ & $68.2 \%$ & $100.0 \%$ \\
\hline
\end{tabular}

TABLE 7:

CHI-SQUARE TESTS FOR TEACHERS VS. STUDENTS ATTITUDES

\begin{tabular}{|l|l|l|l|l|l|}
\hline & Value & Df & Asymp. Sig. (2-sided) & Exact Sig. (2-sided) & Exact Sig. (1-sided) \\
\hline Pearson Chi-Square & $2.736^{\mathrm{a}}$ & 1 & .098 & & \\
Continuity Correction $^{\mathrm{b}}$ & 1.838 & 1 & .175 & .077 & .138 \\
Likelihood Ratio & 3.125 & 1 & .100 & .083 \\
Fisher's Exact Test & & 1 & & \\
Linear-by-Linear Association & 2.711 & 110 & & & \\
N of Valid Cases & & & & \\
\hline
\end{tabular}

\section{Research Question 5}

Is there any difference in male and female students attitudes towards ESP overcrowded classes?

TABLE 8:

ATTITUDES TOWARD LARGE CLASSES IN STUDENTS GROUP IN TERMS OF GENDER

\begin{tabular}{|ll|l|l|l|l|}
\hline & & Frequency & Percent & Valid Percent & Cumulative Percent \\
\hline Valid & male & 49 & 44.5 & 44.5 & 44.5 \\
& famele & 61 & 55.5 & 55.5 & 100.0 \\
& Total & 110 & 100.0 & 100.0 & \\
\hline
\end{tabular}

6. Is there any difference in teachers' attitudes based on their experience years?

Data analysis did not show any significant difference on the basis of years of experience between old and younger teachers. Table 10 illustrates the details of this finding.

TABLE 9:

ATTITUDES OF TEACHERS ACCORDING TO THEIR YEARS OF EXPERIENCE TOWARD ESP OVERCROWDED CLASSES Crosstab

\begin{tabular}{|c|c|c|c|c|c|}
\hline & & & \multicolumn{2}{|l|}{ Teachers } & \multirow[b]{2}{*}{ Total } \\
\hline & & & $\begin{array}{l}\text { Positive } \\
\text { attitude }\end{array}$ & $\begin{array}{l}\text { Negative } \\
\text { attitude }\end{array}$ & \\
\hline \multirow[t]{4}{*}{ Years of expericnec } & $<10$ & Count & 2 & 6 & 8 \\
\hline & & $\%$ within & $25.0 \%$ & $75.0 \%$ & $100.0 \%$ \\
\hline & $>10$ & Count & 0 & 7 & 7 \\
\hline & & $\%$ within & $.0 \%$ & $100.0 \%$ & $100.0 \%$ \\
\hline \multirow[t]{2}{*}{ Total } & & Count & 2 & 13 & 15 \\
\hline & & $\%$ within & $13.3 \%$ & $86.7 \%$ & $100.0 \%$ \\
\hline
\end{tabular}


TABLE 10:

CHI-SQUARE TESTS FOR ATTITUDES OF TEACHERS ACCORDING TO THEIR YEARS OF EXPERIENCE TOWARD ESP OVERCROWDED CLASSES

\begin{tabular}{|l|l|l|l|l|l|}
\hline & Value & Df & Asymp. Sig. (2-sided) & Exact Sig. (2-sided) & Exact Sig. (1-sided) \\
\hline Pearson Chi-Square & $2.019^{\mathrm{a}}$ & 1 & .155 & \\
Continuity Correction & & & \\
Likelihood Ratio & .435 & 1 & 1 & .509 & .095 \\
Fisher's Exact Test & 2.783 & & .170 & .267 \\
Linear-by-Linear Association & 1.885 & 1 & & \\
N of Valid Cases & 15 & & & \\
\hline
\end{tabular}

a. 2 cells $(50.0 \%)$ have expected count less than 5 . The minimum expected count is .93 .

b. Computed only for a $2 \times 2$ table

TABLE 11:

FREQUENCY TABLE FOR ATTITUDES OF TEACHERS ACCORDING TO THEIR YEARS OF EXPERIENCE TOWARD ESP OVERCROWDED CLASSES Analysis by Years of teaching

\begin{tabular}{|ll|l|l|l|l|}
\hline & Frequency & Percent & Valid Percent & Cumulative Percent \\
\hline Valid & $<10$ & 8 & 53.3 & 53.3 & 53.3 \\
& $>10$ & 7 & 46.7 & 46.7 & 100.0 \\
& Total & 15 & 100.0 & 100.0 & \\
\hline
\end{tabular}

As mentioned before table 11 demonstrates there was no significant difference between the attitudes of two groups of teachers who were categorized under 10 years of experience and over 10years of experience. The calculated value was higher than the critical value at 0.05 probabilities. These findings corroborates with Ogunkola,(2004) and Hoxby(2000) that old teachers have over the years found coping strategies to the problem of teaching large classes to the extent that they no longer seems to see the size of classes as a problem.

The following graphs present a snapshot of the above comparisons. As it is clear from the bar graphs there was not a significant difference between the attitudes of the students and teachers on the basis of their gender.

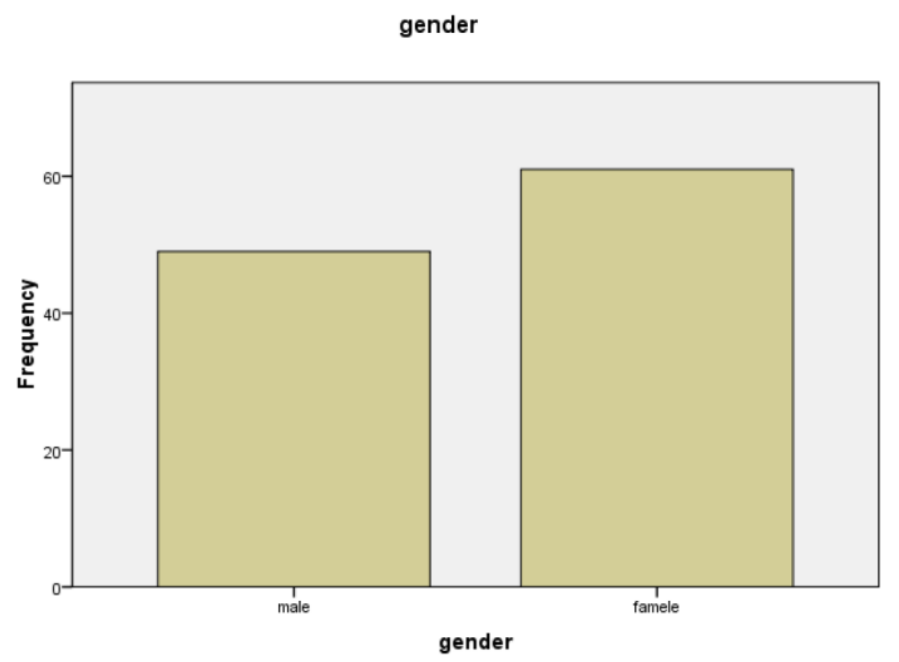

Graph 1: A snapshot of the attitudes in two groups of teachers and students on the basis of their gender 


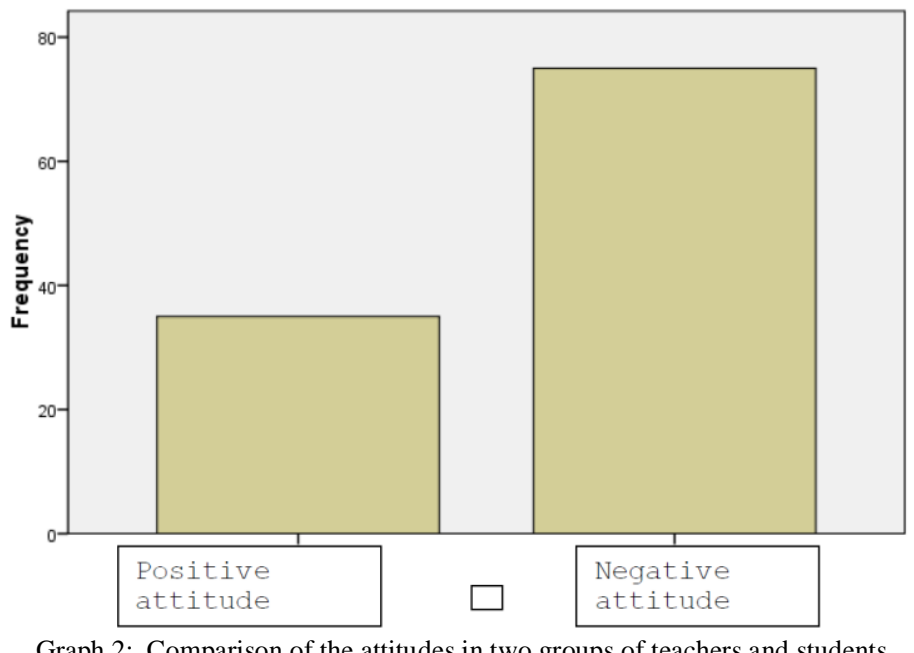

\section{DisCUSSION OF THE RESULTS}

Research findings indicate that overcrowded classes may devalue and degrade ESP classes. Such classes hinder the achievement of the students and are among the factors which lead to diminution of students' grades. The interest and motivation of students are sacrificed for large class sizes, since they do not have opportunity to be demonstrated. Kathey et al (2005) put that: "Class size may affect student attitudes more significantly than it affects achievement; a direct effect of large classsize is to lower the morale and increase the stress of teachers; and there is typically little to be gained from reductions in class size that do not bring class size below 30.

Overcrowded classrooms put students at risk for a lower achievement rate than would likely be seen in smaller classrooms. The higher the student to teacher ratio, the less likely students are to be attentive. This also puts students with disabilities at a disadvantage because they may not get the individualized attention they need. Students who have to wait for help from a teacher would also suffer. This waiting period could lead to disruptive behavior or nonproductive activities, which in turn would lead to strains on the teacher's classroom management and the children's learning (Kathy et al., 2005: --)."

Over the past decades, the percentage of students aspiring to study in medical fields has continued to grow. This aspiration along with the optimistic strategies of policy makers and government in Iran to encourage people to be benefited from higher and free education has resulted in stuffing of classes, while there has been sporadic increase in the facilities and teachers. The problem is more outstanding in ESP classes due to the fact that teachers find it difficult to manage their classes communicatively and to reach optimal criteria. Besides, in the era of mirroring the world as merely a small village where all people are expected to communicate in English to transfer their knowledge and to receive the new research findings which is more critical for specialists, this objective has an opaque future concerning the large classes where our medical students have to attend. The results of this study affirm that students and teachers are encountered with many problems in their ESP large classes. In such populated classes the situation usually happens so that teachers are incapable of recognizing his students. Also multiple classes are usually merged in one class and being taught only by one teacher.

As accounts for the issues of overcrowded classes, Smith (2000) argues that:

'Schools hold the responsibility of providing for students' various needs. Students' needs range from physical to emotional. In the classroom setting, students will need times for group interaction, but will need quiet times alone as well. This need will vary with the students in the classroom. Making space and allowances for that quiet time at any point during the day is helpful to many students."

Within such a framework, the teachers are overwhelmed by a rapid expansion of number of students, without a corresponding expand in the number of students. The burden usually falls on the shoulders of teachers to deal with this inflation in terms of number of students. In parallel to this the quality and efficiency of such classes and quality education and training has become a matter of ivory tower so distant from the fabric of academic life. This problem has led to the escalation of criticism from the part of both teachers and students. In this vein, application of traditional structures of classroom management and teaching does not work and demands a new mould of shaping and reconstruction. Moreover this herald a new focus on delivery and performance or reshaping of classrooms so that they are hand gripped. Not pursuing these mentioned problems risk omitting the term by the students which per se leads to admission of failure. There is a high dissonance between input and output in such classes which is less encumbered by departments. The features of overcrowded classes as mentioned in the questionnaire of this research are not simply an abstract entity and epitomize the challenges of teachers and institutions facing the academy today. These features even are more sheltered in ESP classes where communication lies in its heart. 
As Akinson and Fadukan state in a research from Kolo and Ojo (2006) noted that teacher perceive that class work take a lot of time in teaching large classes. Other viewsof teachers are that exercises are not finished during the forty minutes allocated for teaching making class work to be cumbersome to be handled by one teacher; there is stress and boredom and fatigue in marking and class control. Due to these problems, many good teachers have either resigned or are frustrated. The frustration leads to some teachers not attending classes regularly (Kolo and Ojo, 2006: 18).

The result of the study of Akhtar et al (2012) showed that there was much agreement between the views of students and teachers on the issue. The main thing that places limitation on the interaction between students and teachers as well as on the quality of teaching and learning is seating arrangement (Akhtar et al, 2012: 25).

Earthman (2002) draws from his work that overcrowding has negative influence upon teachers and students. The overcrowding has effects on students learning and students in overcrowded classes do not score as high on achievement test as students in non-overcrowded classrooms (Earthman, 2002: 19).

\section{CONCLUSION, IMPLICATIONS AND SUGGESTIONS FOR FURTHER STUDY}

The recent intense focus on academic accountability in terms of involving much population in higher education programs and overloading classes over their factual capacities has had significant repercussions on the quality of teaching and learning and has led to complaints of teachers and learners in Iran similar to many other countries. This phenomenon is more patent in ESP classes where the essence of teaching lies in interaction. The main objective of this study was to account for the attitudes and perceptions of teachers and learners toward stuffed ESP classes. In essence, the following points epitomize the nature of the challenge of teachers and learners in stuffed classes:

1. Noise making was the most important issue that the teachers had to handle in overcrowded classes.

2. Securing students' total attention in such classes was difficult.

3. Many pupils at the back do not pay attention.

4. It is difficult for students to see students who are not paying attention

5. There was an agreement between the attitudes of both teachers and learners of ESP towards populated ESP classes. They thought of such classes both demanding and challenging.

6. The demanding situation which varies from delivering knowledge to foster independence of learning and interaction as focal points in ESP classes is something awkward and unmanageable in stuffed classes.

7. Overall negative attitudes were the manifestation and outcome which happened in the perception of individuals in our classes.

8. Usually in such classes weaker and slower students are ignored and to come up with the problem of time constraint teachers only ask the help of strong and bright students. Interaction between students and teachers are at the marginal and lowest extent.

This research, very roughly, outlines the shape of the challenge. Alongside and somewhat in response to this challenge the development of new paradigm in realization of learning and teaching expertise and in development of quality teaching are the measurements to be taken in the country.

\section{Implications}

The following recommendations are put forward to deal with the problems arising from overpopulated ESP classes:

1. The number of teachers recruited for higher education be increased.

2. Personalized attention be given to individual students

3. To decrease the burden of teachers some methods of effective teaching be applied. Small group learning could be a suggestion.

4. In overcrowded classes some students may not find an appropriate situation to express themselves. Some methods of teaching can be used to involve less active students.

5. As a suggestion against problems of populated classes, small group work provides opportunities for self reflection, self development and the monitoring of one's own learning which moves the learner towards self direction and independence. (Grandtham 2003, Jacques 2003).

6. A ration of 1: 35 students is a fair alternative to deal with overcrowded classes. It is therefore recommended that our educational policy makers should formulate policies that will ensure that the number of students in a class should not exceed 30 students. This in turn will make the government to provide enough classrooms for the schools.

\section{Suggestions for further study}

Some rules of participation in the activities should be established to prevent interventions which tend to hinder teaching efficacy.

Furthermore, as a complementary investigation, teachers' using specific strategies are suggested to be taken. In this case, the research can be continued to investigate the teachers' influence on students.

Overall, as universities move toward the use of PBL and more students centered education and training, there is a need to discover how to make this alternative more attractive and viable for large class populations.

As this study indicated, the groundwork of the ESP classes is interaction. The ways this interaction can be facilitated in large classes scan be a good area of research.

Some training classes for teachers should be programmed to deal with the problems of overcrowded classes. 


\section{REFERENCES}

[1] Ajayi,K and Ogunyemi B. (1990). The Relationship between Instructional Resources and Socio-Economic Status in selected Population of High Schools in Lagos State. Dissertation/Abstract International, Vol. 25, No. 2. Pages 22-23.

[2] Akinsolu, A.O \&Fadokun, J.B. teachers' perceptions on teaching large classes in secondary schools: Implications for qualitative educational planning and administration. Nigeria, ONDO.

[3] Benbow, J. et al. (2007). Large class sizes in developing world: what do we know and what can we do? USAID U.S Agency for international Development.

[4] Brewer, D.J., A. Gamoran, R.G. Ehrenberg and J.D. Willms. (2001). The Class Size Controversy (CHERI Working Paper No. 14). Cornel University, ILR School. Retrieved from: http://digitalcommons.ilr.cornel.edu/ workingpapers; retrieval time:2012/4/22.

[5] Burnett, G. (1995). Overcrowding in Urban Schools. ERIC/CUE Digest Number Source: Corcoran, T. et al. (1988).Working in Urban schools. Washington D.C Institute.

[6] Dror, Y. (1995). School Location as a Function of Uniqueness, Autonomy Integration and Comprehensiveness: Educational Leadership. Retrieved June 07, 2010 from Educational Planning and Management Ministry of Education, Islamabad. AEPAM Educational Research, 12(1), 111-11

[7] Federal Ministry of Education, (2005). Education Status Report. FME, Publications, Abuja. ERIC Clearinghouse on Urban Education New York NY. 107.ED384682 1995-07-00.

[8] Goettler-Sopko, S. (1990).The effect of class size on reading achievement. ERIC Document Reproduction Service No. ED325826.

[9] Hayes, D. (1997). 'Helping teachers to cope with large classes". ELT Journal, Vol.51 No 2. Oxford University press, 1997.

[10] Hollingworth, P. M. (1992). Class size: An educational issue. Education, 112(3), $412-416$. http://www.escholarship.org/uc/item/5sw56439?display=all.

[11] Ijaiya, N.Y.S. (1999). Effect of overcrowded classrooms on teacher - students' interactions. In Ilorin Journal of Education. Vol.19. pp $1-\mathrm{m} 11$.

[12] Kleiner, C. (2001). The coed way. US News and World Report, 130(9), 44.

[13] Kolo, T.N and Ojo, F.R. (2005). Large classes and Assessment: Problems encountered by teachers in Nigeria secondary schools. A paper presented at the 31st Annual IAEA Conference held at Nicon Hilton, Hotel. Abuja, Nigeria. 4th - 9th September. Lewis.

[14] Kolo, T.N. (1991). Relative effects of class size, Social Educational Background and Attitude on Oral English Proficiency in Nupe Students. Unpublished Ph. D Thesis, University of Ibadan.

[15] Nolasco, R. and Arthur, L. (1988). Large classes: London. Macmillan Publishers.

[16] Obanyan, P.A (1975). 'Oral work in large French classes', In West Africa Journal of Education (WAJE), Vol. 19, N0 3. Pages 361-70.

[17] Pitts, D. L. (1977). A study of the relationship among financial efficiency and school location, school level and academic achievement in selected Texas Districts. Unpublished Ph. D Thesis, University of Houston. Research Study No. 183 iv.

[18] Akhtar, Sh. Lt., Arif, M. Zamurad, N. , and Hussain, I. (2012), Problems Faced by Students and Teachers in the Management of Overcrowded Classes in Pakistan, Language in India.

[19] Sitkei, E.G. (1968). The Effect of Class Size: A Review of Research. Washington, D.C.

[20] Smith, M. (2000). Articles on Personal Space, SDPL articles on classroom size pp.221-.

[21] UNESCO, (2000). The state of education in Nigeria. UNESCO, office Abuja.

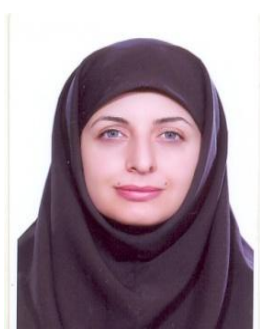

Giti Karimkhanlouei is an Iranian TEFL teacher. She has PHD in TEFL. She teaches in topics related to ESP, theories of learning and teaching, development of reading and writing skills, letter writing at Medical University of Zanjan as a faculty member and the other universities as an invited teacher. Her expertise in health and education has led her to serve as head of English language department and as supervisor of theses of the students. She has dedicated her academic life for over 18 years of teaching courses of English and she has published a few books and articles. Her current research interests are Language teaching and learning with a special focus on students of medicine, e-learning and ESP course evaluation. She is a member of IATEFL and TESOL and has been editor of several books on emerging topics in TEFL

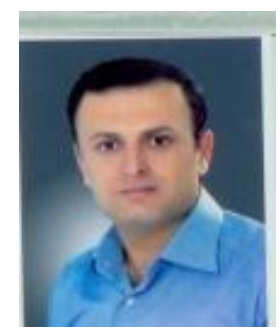

Behzad Rahbar is an Assistant Professor of General Linguistics. He was born on August $16^{\text {th }}$, 1978 in Iran. $\mathrm{He}$ received his PhD in general linguistics in 2010. His fields of study are sociolinguistics, discourse analysis, pragmatics and second language learning. He has published some books and articles in ISI journals and attended some international conferences. He has proposed the Gender Spectrum Model in his PhD thesis and nourished this model in some other articles. He is currently the head of Linguistics Department of Zanjan Branch, Islamic Azad University, Zanjan, Iran. 


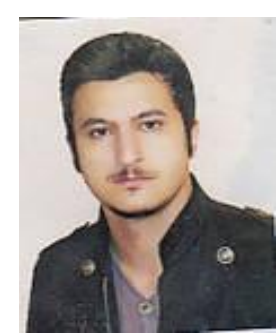

Behzad Bayat was born in 1987 and is an MA student of TEFL. His areas of research interest is Second language teaching 